\title{
The correlation between body mass index and intraocular pressure in children
}

\author{
Correção entre o índice de massa corpórea e a pressão intraocular em crianças
}

Luciano Lira de Albuquerque ${ }^{1}$, Maria Isabel Lynch Gaete ${ }^{2}$, José Natal Figueiroa ${ }^{3}$, João Guilherme Bezerra Alves ${ }^{1}$

\begin{abstract}
Purpose: There is evidence from some studies that support an association between obesity in adults and higher intraocular pressure (IOP). However, this association has not been completely studied in children. Our aim is to evaluate the association between child body mass index (BMI) and IOP.

Methods: Ninety-six children attending the Instituto de Medicina Integral Prof. Fernando Figueira (IMIP) in Brazil were studied. Thirty-three were overweight/ obese with a mean BMI of $29.7 \pm 5.2$ and 63 with a mean BMI of $20.8 \pm 3.3$. IOP was measured using the Goldmann applanation tonometer and was corrected for corneal thickness. The coefficient of correlation between BMI and IOP was calculated. Results: There was no significant difference in the IOP of children with or without overweight/obesity. The mean IOP was 13.5 and $13.0 \mathrm{mmHg}$ for the right eye and 13.1 and $12.9 \mathrm{mmHg}$ for left eye, respectively $(p=0.38$ and $p=0.71)$. The results remained the same after correction by pachymetry; 13.0 and $13.1 \mathrm{mmHg}$ for the right eye and 12.4 and $12.9 \mathrm{mmHg}$ for the left eye, respectively ( $p=0.88$ and $p=0.41)$. The coefficient of correlation between BMI and IOP was $0.070(p=0.496)$. Conclusion: These results do not show a correlation between body mass index and IOP in children. Further studies are warranted to clarify the association between $\mathrm{BMI}$ and IOP in children.
\end{abstract}

Keywords: Intraocular pressure;Tonometry; Body mass index; Obesity; Overweight; Child

\section{RESUMO}

Objetivo: Alguns estudos apontam para uma associação entre obesidade e aumento da pressão intraocular em adultos. Entretanto, essa associação ainda não foi completamente estudada em crianças. O objetivo do estudo é avaliar a associação entre o índice de massa corpórea (IMC) e a pressão intraocular em crianças.

Métodos: Noventa e seis crianças atendidas no Instituto de Medicina Integral Prof. Fernando Figueira (IMIP), Brasil, foram estudadas. Trinta e três apresentavam excesso de peso ou obesidade com uma média de IMC de 29,7 +5,2 e os outros 63 tinham uma média de IMC de 20,8 $\pm 3,3$. A pressão intraocular foi medida por meio do tonômetro de aplanação de Goldmann, corrigida pela espessura da córnea. O coeficiente de correlação entre o IMC e a pressão intraocular foi calculado.

Resultados: Não foi observada diferença significativa na pressão intraocular entre as crianças com e sem excesso de peso/obesidade. A média da pressão intraocular foi de 13,5 e 13,0 mmHg no olho direito e 13,1 e 12,9 mmHg no olho esquerdo, respectivamente $(p=0,38$ e $p=0,71)$. Os resultados permaneceram os mesmos após a correção pela paquimetria; 13,0 e 13,1 $\mathrm{mmHg}$ para o olho direito e 12,4 e 12,9 $\mathrm{mmHg}$ para o olho esquerdo, respectivamente $(p=0,88$ e $p=0,41)$. O coeficiente de correlação entre o IMC e a pressão intraocular foi 0,070 ( $p=0,496)$.

Conclusão: $O$ índice de massa corpórea não parece apresentar correlação com a pressão intraocular em crianças. Novos estudos são necessários para esclarecer a associação entre o IMC e a pressão intraocular.

Descritores: Pressão intraocular; Tonometria; Indice de massa corpórea; Obesidade; Sobrepeso; Criança

\section{INTRODUCTION}

High intraocular pressure (IOP) is associated with glaucomatous optic nerve damage and its detrimental effect on vision ${ }^{(1,2)}$. IOP is currently the only modifiable risk factor for glaucoma ${ }^{(3)}$. Some epidemiological studies have described an association between obesity and IOP in adults ${ }^{(4,5)}$. A recent review concluded that there is an association between higher body mass index (BMI) and higher IOP in adults ${ }^{(6)}$. Although obesity is becoming a serious health problem in children with effects later on in adult life, there is only one study that has determined the IOP in obese children. Akinci et al. found that obesity was an independent risk factor for increased IOP(7). The aim here is to evaluate the association between BMI and IOP in children.

\section{METHODS}

Ninety-six children were recruited from the Department of Pediatrics of the Instituto de Medicina Integral Prof. Fernando Figueira
(IMIP), Brazil, between September, 2009 and March, 2010. The research received prior approval from the Research Ethics Committee and all parents of participants signed an informed consent form.

Weight and height were measured with the children wearing light clothes and no shoes. Body mass index (BMI), weight (in kilograms) divided by height in meters squared $\left(\mathrm{kg} / \mathrm{m}^{2}\right)$, was used as the indicator of fat mass. A child with a BMl in the $95^{\text {th }}$ percentile or higher was considered to be obese, and a child with a BMI $>85^{\text {th }}$ and $<95^{\text {th }}$ percentile was considered to be overweight.

Exclusion criteria included previous glaucoma, orbital masses, severe myopia (>6D), diseases of the cornea or the presence of cardiovascular, renal, neurological, mental or metabolic disorders and genetic syndromes.

All measurements were performed between 9:00 am and midday, by one of the authors (LLA).

The IOP was measured using the Goldmann applanation tonometer. Three sequential measurements were recorded for each eye
Submitted for publication: December 12, 2011

Accepted for publication: December 13, 2012

Study carried out at Instituto de Medicina Integral Professor Fernando Figueira, Recife, PE, Brazil. Physician, Serviço de Oftalmologia Pediátrica, Instituto de Medicina Integral Professor Fernando Figueira, Recife, PE, Brazil.

Professor, Universidade Federal de Pernambuco, Recife, PE, Brazil.

${ }^{3}$ Statistician, Instituto de Medicina Integral Professor Fernando Figueira, Recife, PE, Brazil.
Funding: No specific financial support was available for this study.

Disclosure of potential conflicts of interest: L.L.de Albuquerque, None; M.I.L.Gaete, None J.N.Figueroa, None; J.G.B.Alves, None.

Corresponding author: João Guilherme Bezerra Alves. Instituto de Medicina Integral Prof. Fernando Figueira (IMIP). Rua dos Coelhos, 300 - Boa Vista - Recife (PE) - 50070-550 - Brazil E-mail: joaoguilherme@imip.org.br 
and the average was recorded. Corneal thickness was determined using a noncontact optical scanning slit pachymeter (Orbscan II). Hertel exophthalmometry was also carried out.

Blood pressure was obtained on the right arm, after 5 min rest, using a mercury sphygmomanometer and appropriate sized cuff. After three measurements, the lowest blood pressure value was chosen. Children were classified according to gender, height and age-specific charts.

Student t test was used to assess mean comparisons of continuous variables and the chi-square test for distributions of categorical variables. The association between BMI and IOP was assessed using the Pearson correlation coefficient. A multiple linear regression model was used to analyze the possible effect of confounding variables in the relationship between $\mathrm{BMI}$ and IOP. All tests used a p-value of $<0.05$.

\section{RESULTS}

Ninety-six children (40 boys, 56 girls), aged from 6 to 17 years (11.0 \pm 2.8$)$, were included in the study. 33 were overweight and obese and biological and socio-economical characteristics of overweight/obese and non-overweight/obese children showed statistical differences (Table 1). Twelve children (12.5\%) were obese and $21(21.8 \%)$ overweight; with BMls of $35.1 \pm 5.3 \mathrm{~kg} / \mathrm{m}^{2}$ and $26.7 \pm$ $4.1 \mathrm{~kg} / \mathrm{m}^{2}$, respectively.

There was no difference in IOP between the overweight/obese and non-overweight/obese children. The mean IOP was 13.5 and 13.0 for the right eye and 13.1 and $12.9 \mathrm{mmHg}$ for the left eye, respectively ( $p=0.38$ and $p=0.71$ ). The corneal thickness and exophthalmometry showed no difference among overweight/obese and nonoverweight/obese children (Table 2). The coefficient of correlation between BMI and IOP was $0.070(p=0.496)$. Multiple linear regression analysis with a significance level of 0.20 did not identify any possible confounding factor in the relation between overweight/obesity and IOP (Table 3).

\section{DISCUSSION}

A positive correlation between IOP and obesity has been described in adults, although some studies have shown conflicting results ${ }^{(8,9)}$. The relationship between IOP and obesity in children has not as yet been adequately studied. As obesity tends to continue into adulthood, a positive correlation between $\mathrm{BMI}$ and IOP could indicate that obesity control in children is a crucial strategy for prevention of glaucoma. However, our results did not confirm an association between BMI and IOP. Akinci et al., however, in a study conducted

Table 1. Biological and socio-economical characteristics of overweight/ obese and non-overweight/obese children

\begin{tabular}{|c|c|c|c|c|}
\hline Variable & $\begin{array}{l}\text { Normal } \\
(N=63)\end{array}$ & $\begin{array}{l}\text { Overweight } \\
(\mathrm{N}=\mathbf{2 1})\end{array}$ & $\begin{array}{l}\text { Obese } \\
(\mathrm{N}=12)\end{array}$ & p value \\
\hline Age, mean (sd) & $12.7^{\mathrm{a}}(0.4)$ & $12.0^{\mathrm{a}}(0.7)$ & $9.5^{b}(0.4)$ & $<0.001^{*}$ \\
\hline Skin color (not white) & 65.5 & 75.0 & 86.1 & $0.132^{+}$ \\
\hline $\begin{array}{l}\text { Maternal schooling } \\
>4 \text { years }(\%)\end{array}$ & $58.6^{\mathrm{a}}$ & $100.0^{b}$ & $75.0^{\mathrm{b}}$ & $0.016^{+}$ \\
\hline $\begin{array}{l}\text { Income per capita } \\
(\$ \cup S \pm s d)\end{array}$ & $95.9(9.4)$ & $101.9(14.7)$ & $106.3(8.5)$ & 0.713 \\
\hline SAP (mmHg), mean (sd) & $107.9(2.4)$ & $107.0(3.7)$ & $107.7(2.1)$ & 0.977 \\
\hline DAP (mmHg), mean (sd) & $65.8(1.7)$ & $61.6(2.6)$ & $66.6(1.5)$ & 0.247 \\
\hline
\end{tabular}

in Turkey, showed a positive correlation between IOP and obesity ${ }^{(7)}$. Two factors may explain these different results. First, the mean difference in BMl among the obese children was $29 \mathrm{~kg} / \mathrm{m}^{2}$ in Akinci et al. compared with $36 \mathrm{~kg} / \mathrm{m}^{2}$ in the present study. Secondly, Goldmann tonometry in individuals with a high $\mathrm{BMI}\left(>34 \mathrm{~kg} / \mathrm{m}^{2}\right)$ may falsely increase $I O P^{(9)}$. During the procedure a high BMI may cause compression of the chest and holding of the breath, both of which give rise to an increase in venous pressure and hence raise IOP.

Some authors argue that obesity increases IOP due to an excessive intraorbital adipose tissue deposit, leading to a rise in blood viscosity and episcleral venous pressure, and a consequent decrease in the facility of aqueous outflow. For other authors, obesity only increases IOP when it is associated with insulin-resistance ${ }^{(10)}$. The autonomic dysfunction and the osmotic gradient induced by hyperglycemia with a consequent fluid shift into the intraocular space have been proposed to explain the association between IOP and insulin-

Table 2. Intraocular pressure (IOP), corneal thickness (COT) and exophthalmometry (exo) in normal, overweight and obese children

\begin{tabular}{|c|c|c|c|c|}
\hline \multirow[b]{3}{*}{ Variable } & \multicolumn{3}{|c|}{ BMI } & \multirow[b]{3}{*}{ p value } \\
\hline & $\begin{array}{l}\text { Normal } \\
(N=63)\end{array}$ & $\begin{array}{l}\text { Overweight } \\
(\mathrm{N}=21)\end{array}$ & $\begin{array}{l}\text { Obese } \\
(N=12)\end{array}$ & \\
\hline & Mean (sd) & Mean (sd) & Mean (sd) & \\
\hline IOP right eye (mmHg) & $13.30(0.3)$ & $13.30(0.5)$ & $13.00(0.3)$ & 0.758 \\
\hline IOP left eye (mmHg) & $13.30(0.3)$ & $12.90(0.5)$ & $12.80(0.3)$ & 0.578 \\
\hline COT right eye $(\mu \mathrm{m})$ & $545.20(7.0)$ & $549.10(10.9)$ & $543.20(6.3)$ & 0.895 \\
\hline COP left eye $(\mu \mathrm{m})$ & $546.40(7.0)$ & $549.80(10.8)$ & $545.80(6.3)$ & 0.950 \\
\hline Exo right eye $(\mathrm{mm})$ & $17.27(1.7)$ & $17.31(1.6)$ & $17.56(1.8)$ & 0.893 \\
\hline Exo left eye (mm) & $17.11(1.9)$ & $17.88(1.8)$ & $17.64(1.7)$ & 0.877 \\
\hline
\end{tabular}

Table 3. Linear regression model for intraocular pressure (IOP) on body mass index adjusted for gender, skin color, maternal schooling, age and income per capita

\begin{tabular}{|c|c|c|c|}
\hline & Coefficient & Std. err. & p value \\
\hline \multicolumn{4}{|l|}{ IOP right eye (mmHg) } \\
\hline Female & -0.88 & 0.43 & 0.043 \\
\hline Skin color (not white) & 0.032 & 0.49 & 0.947 \\
\hline Maternal schooling $>4$ years $(\%)$ & 0.28 & 0.49 & 0.563 \\
\hline Age & 0.045 & 0.093 & 0.631 \\
\hline Income per capita & 0.00011 & 0.0042 & 0.980 \\
\hline \multicolumn{4}{|l|}{ Body mass index (reference: normal) } \\
\hline Overweight & -0.30 & 0.64 & 0.634 \\
\hline Obese & -0.45 & 0.055 & 0.416 \\
\hline Constant & 13.21 & 1.34 & $<0.001$ \\
\hline \multicolumn{4}{|l|}{ IOP left eye (mmHg) } \\
\hline Female & -0.69 & 0.43 & 0.113 \\
\hline Skin color (not White) & -0.13 & 0.49 & 0.796 \\
\hline Maternal schooling $>4$ years $(\%)$ & 0.31 & 0.49 & 0.528 \\
\hline Age & 0.030 & 0.094 & 0.747 \\
\hline Income per capita & -0.00028 & 0.0043 & 0.948 \\
\hline \multicolumn{4}{|l|}{ Body mass index (reference: normal) } \\
\hline Overweight & -0.57 & 0.64 & 0.374 \\
\hline Obese & -0.55 & 0.55 & 0.325 \\
\hline Constant & 13.34 & 1.35 & $<0.001$ \\
\hline
\end{tabular}


-resistance. Insulin-resistance is more frequent in children with very high BMI and the present study included overweight/obese children with a mean BMI of $29 \mathrm{~kg} / \mathrm{m}^{2}$.

All examinations were performed at the same time by the study's lead author (LL). All patients underwent pachymetry and exophthalmometry, examinations that increase the reliability of IOP measurement. There is no linear correlation between IOP and corneal thickness, so mathematic attempts to correct the IOP for corneal thickness are not valid. However in our study corneal thickness showed no differences among overweight/obese and non-overweight/ obese children which decrease the influence of this variable on IOP.

A number of shortcomings of this study should be mentioned. First, the study included a few number of obese children with a high BMI, as Akinci et al. did (7). For this reason it is not possible to carry out a comparative analysis among the obese children. It can be hypothesized that IOP increases only in children with extreme obesity. Another point is that the measurement of IOP was performed by only one ophthalmologist and it was not possible to determine the reliability of the test.

In conclusion, no association was found between BMI and PIO in this study. This finding did not confirm previous results that obesity in children is an independent risk factor for IOP. Further studies are warranted to clarify the association between BMI and IOP in children.

\section{REFERENCES}

1. Mackenzie P, Cioffi G. How does lowering of intraocular pressure protect the optic nerve? Surv Ophthalmol. 2008;53 Suppl1:S39-43.

2. Harris A, Rechtman E, Siesky B, Jonescu-Cuypers C, McCranor L, Garzozi HJ. The role of optic nerve blood flow in the pathogenesis of glaucoma. Ophthalmol Clin North Am. 2005;18(3):345-53,v.

3. Coleman AL, Kodjebacheva G. Risk factors for glaucoma needing more attention. Open Ophthalmol J. 2009;3:38-42.

4. Mori K, Ando F, Nomura H, Sato Y, Shimokata H. Relationship between intraocular pressure and obesity in Japan. Int J Epidemiol. 2000;29(4):661-6.

5. Lee JS, Choi YR, Lee JE, Choi HY, Lee SH, Oum BS. Relationship between intraocular pressure and systemic health parameters in the Korean population. Korean J Ophthalmol. 2002;16(1):13-9.

6. Cheung N, Wong TY. Obesity and eye diseases. Surv Ophthalmol. 2007;52(2):180-95. Review.

7. Akinci A, Cetinkaya E, Aycan Z, Oner O. Relationship between intraocular pressure and obesity in children. J Glaucoma. 2007;16(7):627-30.

8. Gasser P, Stümpfig D, Schötzau A, Ackermann-Liebrich U, Flammer J. Body mass index in glaucoma. J Glaucoma. 1999;8(1):8-11.

9. dos Santos MG, Makk S, Berghold A, Eckhardt M, Haas A. Intraocular pressure difference in Goldmann applanation tonometry versus Perkins hand-held applanation tonometry in overweight patients. Ophthalmology. 1998;105(12):2260-3. Comment in Ophthalmology. 1999;106(6):1041.

10. Park SS, Lee EH, Jargal G, Paek D, Cho SI. The distribution of intraocular pressure and its association with metabolic syndrome in a community. J Prev Med Public Health. 2010;43(2):125-30. 